\title{
ВЗАЕМОДІЯ КАНОНІЧНОГО ТА ПУБЛІЧНОГО ПРАВА СЕРЕДНЬОВІЧНОЇ ДОБИ: ПОЛІТИКО-ПРАВОВИЙ ВИМІР
}

Турчак О. В.

Ця стаття присвячена сутності ma змісту взаємодії канонічного та публічного права в добу Середньовіччя. Така взаємодія аналізується у політико-правовому сенсі, де до уваги беруться особливості суспільно-політичного та державно-правового розвитку європейських країн. Досліджуються проблеми організації сфери державних фінансів, особливостей оподаткування, обґрунтування збору коштів на організацію Хрестоносного руху на Схід, головних засад організації та легітимізації церковної влади, тонкощів середньовічної дипломатії, регулюванню міжнародних відносин, правовому вирішенню політичних, територіальних та військових конфліктів moщо.

У статті вказується на те, що у взаємодії середньовічного канонічного та публічного права можна виявити сліди зародження багатьох сучасних ідей по корпоративному праву, податковому праву або державних фінансах і навіть витоки концепцій, базових для конституційної держави, поняття про те, що влада держави повинна бути визначена законом. Вони також заклали концептуальну обгрунтованість діяльності парламентів і подібних до них законодавчих зборів.

Констатуємо, що вплив середньовічного каноніч ного права не був обмежений предметами, що належать до внутрішньої організації та структури церковних інституцій, і воно не було зайнято виключно питаннями доктрини і церковної дисципліни. Різке розмежування, яке сучасні концепції проводять між мирськими справами, світською адміністрацією та публічною політикою, з одного боку, і релігійними проблемами, практикою та інститутами церкви з іншого, було не поміченим тими, хто писав і досліджував ці питання і проблеми в добу Середньовіччя. Умоглядні припущення i гіпотези, які розроблялись середньовічними каноністами, насправді, мали прямий $і$ безпосередній вплив на витоки того, що зараз вважається сучасним $і$ світським. У їхніх працях можна виявити сліди зародження багатьох сучасних ідей з корпоративного права, податкового права або державних фінансів і навіть витоки концепцій, базових для конституційної держави, поняття про те, що влада держави повинна бути визначена законом.

Ключові слова: канонічне право, черковне право, публічне право, Середньовіччя, релігія, держава, Католицька церква.
Turchak 0. V. Interaction of canonical and public law in the Middle Ages: political and legal dimension

This article is devoted to the essence and content of the interaction of canonical and public law in the Middle Ages. This interaction is analyzed in the political and legal sense, which takes into account the peculiarities of socio-political and state-legal development of European countries. Problems of organization of public finance, peculiarities of taxation, substantiation of fundraising for the organization of the Crusade to the East, the main principles of organization and legitimization of church power, subtleties of medieval diplomacy, regulation of international relations, legal settlement of political, territorial and military conflicts, etc. are studied.

The article points out that the influence of medieval canon law was not limited to subjects belonging to the internal organization and structure of ecclesiastical institutions, and it was not occupied exclusively with questions of doctrine and ecclesiastical discipline. The sharp distinction that modern concepts draw between secular affairs, secular administration and public policy, on the one hand, and religious issues, practices, and church institutions - on the other, went unnoticed by those who wrote and researched these issues and problems in the Middle Ages. The speculative assumptions and hypotheses developed by the medieval canonists, in fact, had a direct and immediate impact on the origins of what is now considered modern and secular. In their works can be found traces of the emergence of many modern ideas on corporate law, tax law or public finance, as well as the origins of concepts basic to the constitutional state, the notion that state power should be defined by law. They also laid the conceptual soundness of parliaments and similar legislatures.

We note that the influence of medieval canon law was not limited to subjects belonging to the internal organization and structure of ecclesiastical institutions, and it was not occupied exclusively with issues of doctrine and ecclesiastical discipline. The sharp distinction that modern concepts draw between secular affairs, secular administration and public policy, on the one hand, and religious issues, practices, and church institutions, on the other, went unnoticed by those who wrote and researched these issues and problems in the Middle Ages.

Key words: canon law, church law, public law, Middle Ages, religion, state, Catholic Church.

(C) Турчак О. В., 2020 
Постановка проблеми. Система канонічного права разом зі своїми суддями, судами, адвокатами і виправними санкціями все ще продовжують діяти у сучасних суспільствах з католицькою вірою, хоча в більшості країн рішення, засновані на канонічному праві, вже не мають адміністративної підтримки з боку світської влади. Сучасне канонічне право застосовує свою ефективність на вільній згоді віруючих з визначеннями, які виносять церковні суди. Члени тих християнських конфесій, які зберігають систему канонічного права (в основному це католики, англікани, східні православні християни), передбачають як умови членства у своїх церквах апріорну згоду з канонічними суддями в їхній професійній діяльності та підпорядкування їх рішенням.

У цьому, безумовно, позиція сучасного канонічного права радикально відрізняється від реальності середньовіччя. Ф. Мейтланд стверджував, що «середньовічна церква була державою» i було важко і навіть неможливо дати визначення державі, яке не можна застосувати до церкви у Середні віки [11, с. 100]. Фактично так і було, середньовічна церква розділяла владу зі світськими правителями: в кожному регіоні канонічне право діяло паралельно з іншими правовими системами. Королівські, місцеві та міські суди здійснювали свої функції в рамках своєї юрисдикції, поруч з ними діяли і церковні суди, при цьому кожна з цих судових систем володіла силою примусу, яка змушувала підкорятися своїм нормам непокірних. Правильно також і те, що канонічна юрисдикція і різні світські юрисдикції часто перетиналися. Вибираючи, до якого суду подати скаргу, щоб отримати бажане рішення і з найменшими затратами, сторона позивача прагнула взяти гору над відповідачем. Відповідач, якщо він володів певними ресурсами і був знайомий з правом, міг, відповідно, використовувати конкуруючі правові норми для перешкоджання тим, хто подав на нього скаргу.

Метою цієї статті $\epsilon$ аналіз політико-правових аспектів взаємодії канонічного і публічного права у період Середньовіччя.

Стан дослідження проблеми. Проблемами середньовічного канонічного, церковного та публічного права займалась низка відомих західних дослідників, зокрема: М. Барбер, М. Бейджент, Дж.Г. Берман, Н. Дейвіс, А. Демурже, Л. Джероза, Ф. Кардіні, Б. Куглєр, Ж. Ле Гофф, Д. Легман, Дж. Ліберо, Дж.Г. Лінч, П. де Лоб'є, Р. Мак Брейн, Ф. Мейтланд, Ж. Рішар, Д. Робінсон, К. Хілленбрандт та ін.
У вітчизняній історіографії ця проблематика представлена працями Г. Арцишевського, Д. Забзалюка, Л. Лазора, В. Лазора, В. Лубського, С. Місевича, С. Сливки, М. Шамшиної.

Виклад основних положень. Складна, делікатна і тому суперечлива низка питань у добу Середньовіччя в публічному праві сконцентрувалася навколо проблеми державних фінансів. Зокрема, одним із ключових було питання, за яких обставин, для яких цілей правитель був правомочний вимагати від своїх підлеглих віддати частину свого майна йому у вигляді податків?

Відповіді на ці питання, які часто-густо суперечили одні одним, породжували суперечки з питань публічного права протягом досить тривалого часу і навіть нині існують сильні розбіжності і суперечки, неминуче пов'язані з питаннями не тільки права, але й питаннями моралі і політики.

На початку своєї історії сама церква була експериментатором у галузі прямого оподаткування всього населення, починаючи з десятини, яку в принципі повинен був платити кожен християнин. Церковна влада могла посилатися на авторитет Священного писання для правового обґрунтування оподаткування десятиною. Початок цьому було покладено у 1166 році, i продовжилося в 1185 i 1188 роках, коли папи наполягали, щоб усі християни, включаючи кліриків, окрім десятини, відмовилися ще від однієї частини свого майна для захисту Святої землі від набігів мусульман. Папська адміністрація не могла ефективно впровадити такі схеми оподаткування без співпраці зі світськими правителями, і тому збір коштів на Хрестові походи в XII столітті був підтриманий королями Англії та Франції. Монархи незабаром зрозуміли, що зібрані таким чином гроші можуть бути використані на різні цілі, і що хоча імм необхідно було стати хрестоносцями, але це не означало негайне і обов'язкове відбуття у Святу землю.

Королям іноді вдавалося відкласти свій від'їзд на десятиліття, а деякі навіть вмирали ще до свого від'їзду в похід на Єрусалим. Наприклад, король Англії Генріх III ставав хрестоносцем не менше трьох разів протягом свого більш ніж п'ятдесятирічного правління, але помер у 1272 році, так жодного разу і не зробивши спроби відправитися у Святу землю. Але водночас податки на потреби Хрестових походів давали скарбниці значний приріст коштів, які монарх міг використовувати на різного роду повсякденні потреби, деякі з яких тільки побічно були пов'язані з Хрестовими походами, а деякі і зовсім не мали до них ніякого відношення [5, с. 328]. 
Зовсім не дивно, що монархи, котрі помітили настільки корисні властивості податків на Хрестові походи, для вирішення своїх внутрішніх проблем 3 грошима самі бажали обкладати податками власників землі у своїх королівствах як кліриків, так і мирян, не чекаючи, поки таку ініціативу проявить Папа Римський, і без певних зобов'язань, нехай хоча б навіть і таких нечітких, як Хрестовий похід на Єрусалим. Безумовно, Папа Римський противився таким діям, особливо коли йшлося про обкладення податками церковної власності. Так, зокрема, протистояння короля Франції Філіпа IV Красивого і Папи Римського Боніфація VIII відновлювалося неодноразово i, врешті-решт, король Франції переміг. Наслідки цього широко відомого протистояння створили прецедент для тотального прямого державного оподаткування, що і до наших днів залишається однією з найбільш значущих прерогатив держави.

Як Хрестові походи давали папам у середні віки правову основу для повсюдного прямого оподаткування, так і захист держави від ворогів давав монархам законний привід для оподаткування своїх підданих різними повинностями. Але потреба в додаткових надходженнях до скарбниці під час війни не була просто результатом прерогативи короля або просто приводом. Зміни як у військовій справі, так і в соціальній структурі суспільства протягом XIII-XV ст. перетворили військову справу з нерегулярного заняття дворян, землевласників і лицарів на дуже складну справу, яка потребує професіоналізму і більше знань, ніж раніше. Нові прийоми ведення війни вимагали наявності інженерів, фахівців з будівництва фортифікаційних споруд, бомбардирів і артилеристів, а також інших професіоналів. Це разом з використанням найманого війська, збільшення якого ставало все більш актуальним, а в підсумку для повної заміни колишніх рекрутів важкої феодальної кінноти були потрібні значні кошти, однак традиційні шляхи збору грошей не покривали зростаючі потреби [5, с. 345].

Навіть у мирний час повсякденні витрати на державні справи росли, оскільки освічені й розумні чиновники, багато з яких були випускниками правових шкіл, починали поступово витісняти на ключових постах феодальних магнатів, членів королівських рад і аристократів, які випадково потрапили на ту чи іншу посаду, і які працювали в королівській адміністрації чи засідали в королівських судах. У XIII столітті почалася епоха бюрократії, а будь-який чиновник-бюрократ повинен отримувати оплату, як правило, грошима, а не натурою за адміністративну роботу, яку він виконував [1, с. 219].

Ці тенденції разом зі зростаючими амбіціями і владою королів надали державним фінансам вирішальну роль на політичній сцені, позаяк раніше вони не були настільки важливі для державного управління. Королівське оподаткування та інші проблеми отримання доходів у казну, такі як державний борг, ставили моральні проблеми і теоретичні завдання разом з політичною доцільністю, і все це цікавило теоретиків канонічного права тією же мірою, як і королівську адміністрацію. «Церква і казначейство йдуть у ногу» [9, с. 260], писав великий юрист того часу Бартолюс. Казначейство також, як і церква, було безсмертним, а, отримавши одного разу будь-яке майно, рідко випускало його з рук. Церква теж була великим власником у будь-якій європейській державі, і монархи, зрозуміло, бажали оподатковувати церковне майно в тому ж розмірі, тими ж способами і за тих же приводів, як і майно мирян. Королівська адміністрація європейських монархів не тільки стверджувала, що клірики користуються захистом від зовнішніх ворогів, що надається державою, рівно тією ж мірою, якою нею користуються миряни, і тому церква несе такі самі обов'язки з відшкодування витрат на оборону держави. Духовні особи зі свого боку намагалися всіма доступними їм заходами протистояти цим спробам обкладати їх податками. Вони стверджували, що церковна власність призначена обслуговувати духовні потреби кожного члена християнського суспільства, і відчужувати цю власність з метою задоволення мирських потреб або примх світських монархів $є$ нічим іншим, як насильством над канонами церкви і намірами жертводавців. Церковна влада передбачала, що якщо дозволити світській владі оподатковувати церковне майно, то незабаром це могло привести до контролю або навіть конфіскації матеріальних ресурсів, які давали церкві іï незалежність від контролю світської влади. Вони добре знали, що влада оподаткування може знищити кого завгодно.

Знавці канонічного права і церковна практика зіграли ключову роль у розвитку середньовічної дипломатії. Королівська та папська адміністрації давно володіли засобами обміну інформацією про свою політику, точку зору і наміри в періоди кризи. У період раннього середньовіччя i аж до середини XIII століття вони зазвичай робили це за допомогою спеціальних посланців, які призначалися задля цієї мети, нунціїв або легатів, які передавали повідомлення і отримували відповіді 
від глав відповідних держав, коли у цьому була необхідність. Ці посланці, яких ще іноді називали «живими листами», просто доставляли кореспонденцію або інформацію, довірену ї, і не мали повноважень змінювати на переговорах позицію, яку заявляв їхній правитель, або вести переговори за нього [8, с. 91]. Проте наприкінці XII століття папи і єпископи почали іноді використовувати інший вид представництва - Прокторів, яким надавалися всі повноваження для ведення переговорів від імені тих, ким вони були послані. Поступово монархи та інші правителі теж стали відправляти представників з повноваженнями (тобто повноважних представників) вести переговори, укладати договори та інші угоди від імені своїх довірителів. Протягом XIII століття повноважні представники стали улюбленим способом встановлення зв'язку правителів між собою. У XIV ст. монарші особи мали все більше приводів для усвідомлення утилітарності змісту одного або більше таких представників на постійній основі за кордоном, тому що тільки вони могли дати швидку поряду своєму довірителю про проблеми і кризові ситуації відразу у разі їх виникнення і навіть могли вжити необхідних у такій ситуації заходів прямо на місці. Це означало початок практики утримувати резидентних посланців при іноземних королівських дворах і наділення їх повноваженнями вести дипломатичні відносини від імені правителя, якого вони представляли [8, с. 98].

Правила, що регулювали в період пізнього середньовіччя дипломатичну практику і міжнародні відносини, виникли на основі канонічного i римського права, рівною мірою запозичивши з обох джерел. Таким же чином розвивалися закони, якими керувалися, продовжуючи дипломатію іншими засобами, тобто війною. Хоча на перший погляд фраза «закони війни» здається оксюмороном, тобто дотепно-дурним стилістичним зворотом, проте помітне протиріччя не важко вирішити. Військові дії майже неминуче ведуть до псування майна, тому суспільство має потребу в правових нормах, що визначають, коли i за яких умов завдані збитки можуть привести до зобов'язань здійснити реституцію і яка процедура повинна бути використана, щоб задовольнити претензії по нанесеному війною збитку. Способи ведення війни в середні віки, як і сьогодні, зазвичай вели до захоплення в полон однієї зі сторін, а, як правило, обома протидіючими сторонами, ворожих солдат. Правила щодо звільнення, викупу або обміну ув'язненими були дуже важливі для обох сторін. Адже наслідком війни часто було захоплення не тільки людей, а й майна.

Правове вирішення конфліктів вимагало деяких узгоджених стандартних понять для визначення прав володіння захопленим майном, наприклад, за яких обставин солдат міг по праву володіти речами убитого противника? Хто ставав власником землі і будівель, захоплених у битві? Солдат, який ними заволодів? Його командир? Монарх, який переміг у війні? Для кожного з цих питань можна було привести реальний випадок його виникнення, і уніфіковані правила були необхідні для вирішення претензій конфліктуючих сторін. Такі ж правила були потрібні і для вирішення інших питань, пов'язаних з дисципліною в армії, з правами осіб, які не $\epsilon$ солдатами, в зоні бойових дій, з формальностями, необхідними для ініціювання військових дій або для оголошення тимчасового перемир'я, а також з процедурою припинення війни і підписання миру [7, с. 311].

Закони війни у середні віки значною мірою залежали від звичної для військових практики, у формі звичаю, але вони були схильні до змін, тому що не були точно визначені, і не завжди і не всюди виявлялися узгодженими. Люди, які знаються на цивільному і канонічному праві, бачили в такій ситуації і розумні зміни, і практичну задачу особливої важливості. Каноністи і світські правознавці в єдиному прагненні домагалися встановлення порядку в неясних, суперечливих і різноманітних нормах, вироблених звичаями. Вони застосовували принципи і прийоми аналізу, відомі ім з римського права для отримання механізмів вирішення домагань конфліктуючих сторін на власність і компенсацію, які з неминучістю породжувалися війною і будь-якими бойовими діями. Цей підхід ясно проглядається в трактатах «Про війну, удар у відповідь і поєдинок» i «За мир», написаних Джованні да Леньяно. Джованні да Леньяно був не тільки професором канонічного права в університеті Болоньї, але і досвідченим дипломатом, який часто виступав як повірений різних італійських міст-держав і Папи Римського в періоди бурхливих і часом жорстоких криз, які переповнювали італійську політику в XIV столітті. Таким чином, він привніс у вчення про мир і про війну не тільки глибокі теоретичні знання, а й практичний досвід, особливо у вирішення проблем, що виникали в міжнародних конфліктах [5, с. 226].

Праці Джованні да Леньяно синтезують великий обсяг попередньої правової думки і роздумів про наслідки насильницьких зіткнень між 
державами. Війна, насильство і проблеми права, які вони породжують, були детально висвітлені в «Декретах» Граціана, так що професори і автори трактатів з канонічного права до XIV століття вже мали традиції викладу і міркування на ці теми, позаяк їм було звідки все це почерпнути.

Джованні да Леньяно був першим, хто синтезував доктрини всіх попередніх авторів у логічно послідовне дослідження не тільки способів ведення війни, а й правову основу для взаємин між монархами. Його трактат про війну розглядає багато проблем, які виглядають прозаїчно, але дуже важливі, такі як розмір виплат найманим військам і коли їх слід виплачувати, чи слід платити наймиту платню, коли він хворий, а також правила, які стосуються тримання військовополонених і до розподілу трофеїв між війнами армії переможниці. На додаток до цього кола земних проблем Джованні да Леньяно розглядає більш піднесені дипломатичні проблеми оголошення війни і укладення миру, так само, як моральні і етичні принципи, які, на його думку, повинні визначати ці питання в християнському суспільстві [5, с. 231].

Таким чином, вплив середньовічного канонічного права не був обмежений предметами, що належать до внутрішньої організації та структури церковних інституцій, і воно не було зайнято виключно питаннями доктрини і церковної дисципліни. Різке розмежування, яке сучасні концепції проводять між мирськими справами, світською адміністрацією та публічною політикою, з одного боку, і релігійними проблемами, практикою і інститутами церкви - з іншого, було непоміченим тими, хто писав і досліджував ці питання i проблеми в добу Середньовіччя. Умоглядні припущення і гіпотези, які розроблялись середньовічними каноністами, насправді, мали прямий і безпосередній вплив на витоки того, що зараз вважається сучасним і світським. у їхніх працях можна виявити сліди зародження багатьох сучасних ідей з корпоративного права, податкового права або державних фінансів і навіть витоки концепцій, базових для конституційної держави, поняття про те, що влада держави повинна бути визначена законом. Вони також заклали концептуальну обґрунтованість діяльності парламентів і подібних до них законодавчих зборів.

Висновок. Середньовічне канонічне право залишається не тільки головним джерелом релігійного права, але й життєво важливим елементом сучасних світських правових систем, особ- ливо у цивільному праві. Міркування і висновки середньовічних каноністів залишаються втіленими в традиції загального права в англомовному світі і правовій спадщині країн континентальної Європи. Це можна наочно продемонструвати, розглядаючи питання, пов'язані із заповітом і сімейним правом, але канонічна традиція проявляє себе і в багатьох інших галузях права: контрактне та корпоративне право, право власності входять в їх число. Канонічні ідеї і технічні питання застосування права ще більш очевидно присутні в багатьох процесуальних нормах, застосовуваних у судах країн континентальної Європи, і навіть зачіпають матеріальне право цих країн. Політична думка та ідея конституційного правління багато взяли з того, що розглядалося канонічним правом у цій галузі в XII-XIII ст. Таким чином, середньовічне канонічне право утворює фундаментальну силу, що постійно розвивається, зі створення певних елементарних ідей та інститутів, які до наших днів продовжують характеризувати європейські суспільства.

\section{Література}

1. Берман Дж. Гарольд. Вера и закон: применение права и религии / пер. с. англ. яз. Москва : Московская школа политических исследований, 2008. 464 c.

2. Джероза Ліберо. Церковне право / пер. з нім. Н. Щиглевської. Львів : Свічадо, 2001. 336 с.

3. Забзалюк Д.Є. Політико-правові детермінанти епохи Середньовіччя в Західній Європі: доктринальне осмислення. Науковий вісник Львівського державного університету внутрішніх справ. Серія юридична. Випуск 4. Львів, 2015. С. 3-11.

4. Забзалюк Д.Є. Хрестоносний рух і політико-правова доктрина доби Середньовіччя: головні детермінанти становлення та розвитку. Науковий вісник Львівського державного університету внутрішніх справ. Серія юридична. Випуск 4. Львів, 2017. С. 13-20.

5. Зайбт Ф. Блиск і вбогість Середньовіччя. Історія з початком і кінцем / перекл. з нім. Х. Назаркевич, О. Конкевич, наук. ред. Р. Паранько. Львів : Видавництво Українського Католицького Університету, 2009. 512 с.

6. Лазор Л.И., Лазор В.В., Шамшина И.И. Каноническое право : учебник. 1-е издание. Луганск : Изд-во 000 «Виртуальная реальность», 2010. 568 c.

7. Ле Гофф Ж. Рождение Европы / пер. с фр. А. Поповой. Санкт-Петербург : Alexandria, 2007. 391 c. 
8. Ле Гофф Ж. Цивилизация средневекового Запада / пер. с фр., ред. В.А. Бабинцева. Послесловие А.Я. Гуревича. Екатеринбург : У-Фактория, 2005. 568 c.

9. Лінч Дж. Середньовічна церква. Коротка історія / пер. з англ. В. Шовкуна. Київ : Основи, 1994. 492 c.

10. Религия и общество. Хрестоматия по социологии религии. Часть I / под общ. ред. В.И. Гараджи. Москва : Наука, 1994. 300 с.
11. Maitland F.W. Roman canon law in the Church of England. London. 1898. 184 p.

Турчак O. В., доктор юридичних наук, професор, начальник науково-дослідної лабораторії (військово-історичних досліджень) Наукового чентру Сухопутних військ Національної академії сухопутних військ імені гетьмана Петра Сагайдачного 